colouring matters in the shells of birds' eggs. Permit me to call attention, through your journal, to a long and detailed paper on this subject published by me, about four years ago, in the Proceedings of the Zoological Society of London. Appa. rently the authors who have lately treated on this subject bave not been aware of the existence of this paper. As far as they go, the facts they have described fully confirm my conclusions; but, as I have shown, different birds' eggs contain at least five perfectly distinct coloured substances, and not, as Liebermann says, only two. One of these is closely related to a product of the decomposition of hæmoglobin and another to the bile pigments, it and the bile of birds yielding the same well-marked product on oxidisation.

Kingstown, Dublin, August 6

H. C. SORby

\section{The Limbs}

IN his interesting papers on "The Genesis of the Limbs," which have recently appeared in NATURE, Mr. Mivart mentions that $I$ have represented the limbs as modified portions of a primitively continuous inferior azygos fin.

That view was stated by me at length in a paper in the Fournal of Anatomy and Physiology, 187x, vol. v., p. 59. It was formed from the following considerations among others-First, that the mesial, or azygos fins, are essentially double organs, being formed from the coalesced elements of the dorsal and ventral plates of the two sides, and being furnished with muscles, nerves, and blood-vessels, from the two sides. They may therefore be the representatives of organs which remain double, that is, of organs in which the lateral elements do not coalesce. Secondly, the limbs and the azygos fins do not co-exist in the same region. The limbs are formed where the ventral plates are kept apart and expanded by the presence of the visceral cavity, so that the elements which in the dorsal and postanal regions meet and unite into azygos fins, are here separated and grow out as lateral limbs. The ventral plates are, moreover, continued onwards beyond the outgrowing line of the limbs, and form the median portion of the visceral wall which lies beneath and between the limbs on the two sides. Thirdly, there is such a marked resem blance between the ventral fins in some fishes and the anal fins, that the transition from the one to the other is easy; the daggershaped pelvic bones being the representatives of two or more coalesced intraspinous bones and the ray bones of the one set being, in like manner, the representatives of the ray bones of the other.

Mr. Balfour in his admirable papers on "The Development of Elasmobranch Fishes," in the Fournal of Anatomy and Physio. logy shows (vol. xi. p. 133), that the limbs are the remnants of continuous lateral fins, and that the ridges from which they are developed are in every way like the folds from which the unpaired fins are formed, but the development and growth are confined to two special points on each side instead of being continued, as in the case of the dorsal and anal fins, along a greater length of the fold. He further remarks that, externally, they closely resemble the unpaired fins, and both their position and nervous supply indicate that they do not belong to one special segment of the body. The lateral ridges, from which they are developed, I conceive to be the continuations of the diverging lateral halves of the essentially double ridge of the caudal fin kept asunder by the presence of the visceral cavity. These are but little separated in the position of the ventral fins, and are more so in the position of the pectoral fins. If this be so, the limbs are specialised differentiations of primitively continuous lateral folds - of portions, "that is, of the diverging plates of the median fold from which the caudal fin is developed.

I cannot, however, assent to Mr. Mivart's view that the limbs are mere appendages to the axial system, or admit that either they or the limb girdles are the result of centripetal growth, "due to the in growth of originally superficial structures-exoskeletal hardenings which have grown inwards and become endoskeletal." The limb girdles are found in the same plane of the mesoblast as the ribs, and are, as I have shown in the "Anatomy of the Cryptobranch" (Fournal of Anatomy, vol. vi. p. 9, and Observations on Myology), though not necessarily the serial homologues of the ribs, yet like them the result of ossification in the ventral transverse intermuscular septa. As they grow out they carry before them envelopes not only of skin, but of muscle, derived from the body-wall, which become differentiated according to the requirements. Moreover, although 'the ridges from which they are primarily developed may appear at first as epiblastic projections, these are soon supplemented by acctumulations of mesoblastic tissue in which the components of the limbs are chiefly formed.

Cambridge, August I

G. M. HUMPHRY

\section{The Darkness of Caverns}

THE impenetrable darkness of caverns has been for a very long time a recognised fact, without its cause having been satisfactorily explained. This darkness vanishes but partially before torch-light, and that oniy in a very limited radius. I, in $m y$ explorations in the caverns of Spain, had also noticed this circumstance, and now that I have verified it in others in Switzerland, I venture to think that I have found the explanation of this phenomenon.

The walls as well as the roof and floor of caverns are continually covered with moisture, which works without interruption in condensing the corpuscles that float in that circumscribed space. It thus performs the same function that the glycerine does which varnishes the sides of the crystal box by means of which Prof. Tyndall obtains an optical vacuum, the light diffusing itself imperfectly from want of those atoms which act as reflecting bodies. I have had occasion to verify my supposition by scattering around the torch very fine dust of different sub. stances. The brightness diffused itself regularly all the time that the dust maintained itself in the required state of closeness and fluctuation, and vanished again slowly as the dust spread or deposited itself. The earth or common dust is the one which, in my experience, has produced the best effect.

Salvador Calderon

\section{Scent and Colour in Flowers}

THE extension of our perceptive faculties of sight and hearing by various optical and acoustical instruments may enable us to comprehend the possibility of these faculties existing in other creatures to a degree so far surpassing ours as to seem a difference almost of kind. So the sight of the vulture would seem to be paralleled by the faculty of smell in moths, as evidenced by the detection of distant females by males. It would seem probable that the sense of smell may guide insects at a far greater distance than that of vision; for a consideration of the structure of the eyes of insects leads to the belief that they are not capable of forming clear images of distant objects. While, then, the scent of its blossoms may attract insects to a plant, their colour will act as a subsequent guide to the individual flowers, just as variegations undoubtedly act as honey-guides when the insect reaches the flower. This view is borne out, firstly, by the undoubted connection between perfume and pollination, shown by Morren in the case of the orchid Maxillaria, whose aromatic perfume lasts till pollination; and, secondly, by the well known connection of odour both with colour and with natural groups, white flowers being mostly sweet-scented, brown and orange ones most fetid. The insect could thus identify species before seeing them. Mr. Wallace has been, perhaps justly, blamed by a writer in the Gardener's Chronicle for saying that brightly. coloured flowers are seldom scented, and Dr. Taylor by "J. S. G." (NATURE, vol. xviii, p. 277), for saying that white flowers open mostly at night. It would, I think, be truer to say that few flowers are both variegated and scented, i.e., that scented flowers are mostly monochromous, and that the majority of nightblowing flowers are white. The latter is a very different matter from saying that the majority of white flowers are night-blowing. We can perceive with difficulty that one part of a flower is more scented than another, yet scent may replace the dots and pointindicating lines of variegation to the senses of an insect. Nature not only often effects one purpose by divers means, but also uses one means for divers ends; so just as colour exists in plants, not only to attract insects, we can understand it being absent in some white flowers simply as a phenomenon of degradation and not as one of specialisation. The dog-rose, white convolvulus, and daisy, mentioned by Mr. Gardner as closing at eventide, are all scentless. The first, according to Dr. Hermann Muiller, is visited by six hymenoptera, two diptera, and twelve coleoptera. The convolvulus does not close till between eight and ten P.M., and re-opens by moonlight. It is visited by two diptera, Podura Thrips, one coleopteron, two hymenoptera, and the Sphinix con 